\title{
Zoogeographical patterns of flatfish (Pleuronectiformes) parasites in the Northeast Atlantic and the importance of the Portuguese coast as a transitional area
}

\author{
JOANA FERREIRA MARQUES ${ }^{1}$, MARIA JOÃO SANTOS ${ }^{2,3}$ and \\ HENRIQUE NOGUEIRA CABRAL ${ }^{1,4}$ \\ ${ }^{1}$ Universidade de Lisboa, Faculdade de Ciências, Instituto de Oceanografia, Campo Grande, 1749-016 Lisboa, Portugal. \\ E-mail: jimarques@fc.ul.pt \\ ${ }^{2}$ Universidade do Porto, Faculdade de Ciências, Departamento de Zoologia e Antropologia, Praça Gomes Teixeira, 4099- \\ 002 Porto, Portugal. \\ ${ }^{3}$ CIMAR Laboratório Associado / CIIMAR, Rua dos Bragas, 177, 4050-123 Porto, Portugal. \\ ${ }^{4}$ Universidade de Lisboa, Faculdade de Ciências, Departamento de Biologia Animal, Campo Grande, 1749-016 Lisboa, \\ Portugal.
}

\begin{abstract}
SUMMARY: Parasites are recognised as an excellent source of information on the distribution of their hosts. Here, the macroparasite fauna of 20 species of Pleuronectiformes belonging to five different families and inhabiting the Portuguese coast was investigated and compared with that known in four other areas (the North Sea, north Northeast Atlantic, Mediterranean Sea and Northwest African coast) in order to determine (1) their zoogeographical pattern and (2) the role of the Portuguese coast as an intermediate biogeographic province. Macroparasites infecting Pleuronectiformes sampled along the Portuguese coast were collected using standard parasitological techniques, whereas data on those in the other four areas were obtained from the literature, rendering a total of 73 macroparasite species. Both sets of data were then compiled in a presence/absence matrix. Hosts and macroparasites were placed into zoogeographical categories according to their known distribution, and patterns were evaluated using multidimensional scaling and cluster analysis. The zoogeography of hosts and parasites was not entirely concordant, although that of endoparasites was generally consistent with the patterns for marine free-living species. On the other hand, only specific ectoparasites truly mirrored the distribution of their hosts. These differences reflect the importance of host ecology and dispersal and environmental factors on the patterns revealed. The Portuguese coast seems to play a significant role in the distribution of Pleuronectiformes' parasites along the Northeast Atlantic and Mediterranean Sea, due to its transitional character and to the sympatric occurrence of related hosts, both promoting the acquisition of new parasite species or the maintenance of historical host-parasite relationships.
\end{abstract}

Keywords: biogeography, macroparasites, Pleuronectiformes, Northeast Atlantic, Mediterranean Sea, multivariate analyses.

RESUMEN: PATRONES ZOOGEOGRÁFICOS DE PARÁSITOS DE PLEURONECTIFORMES DE LA COSTA PORTUGUESA Y SU IMPORTANCIA COMO ÁREA DE TRANSICIÓN. - Los parásitos son reconocidos como una excelente fuente de información de la distribución de sus hospedadores. En este estudio, la fauna parasitaria de 20 especies de Pleuronectiformes, pertenecientes a cinco familias, que habitan la costa Portuguesa fue analizada y comparada con la conocida en otras cuatro áreas (Mar del Norte, norte del Atlántico Nordeste, Mediterráneo y costa del noroeste Africano) para determinar (1) sus patrones zoogeográficos y (2) el papel de la costa portuguesa como una provincia biogeográfica intermediaria. Los macroparásitos de los pleuronectiformes encontrados en la costa portuguesa fueron recogidos de acuerdo con las técnicas estándar en parasitología y los de las otras cuatro áreas fueron recopilados de la literatura, totalizando 73 especies. Ambos tipos de datos fueron posteriormente compilados en una matriz de presencia/ausencia. Hospedadores y macroparásitos fueron clasificados en categorías zoogeográficas, de acuerdo con su distribución y los patrones obtenidos mediante análisis multidimensional y de clúster. La zoogeografía de hospedadores y parásitos no fue totalmente concordante, aunque la de los endoparásitos fuera, en general, consistente con los patrones referidos para las especies marinas de vida libre. En cambio, sólo los ectoparásitos específicos reflejaron 
verdaderamente la distribución de sus hospedadores. Estas diferencias reflejan la importancia de la ecología y dispersión de los hospedadores y de los factores ambientales en estos patrones. El carácter de transición de la costa portuguesa y la existencia simpátrica de hospedadores relacionados, contribuyen a que esta región desempeñe una función muy importante en la distribución de los macroparásitos de los pleuronectiformes del Atlántico nordeste y del Mediterráneo, ya que promueven la adquisición de nuevas especies de parásitos o el mantenimiento de las relaciones históricas hospedadores-parásitos.

Palabras clave: biogeografía, macroparásitos, pleuronectiformes, Atlántico nordeste, Mediterráneo, análisis multivariante.

\section{INTRODUCTION}

The last decade has seen increased interest in host-parasite relationships in ecological studies, with parasites providing important information about their hosts biology, ecology, phylogeny and population structure. Since it is highly improbable that parasite species are distributed randomly among their hosts, the geographical variation of the occurrence and abundance of parasite species is regarded as an excellent source of information on the geographic distribution and migration routes of marine fishes (Mosquera et al., 2000; Poulin and Morand, 2000). However, though studies using parasites of marine fishes as indicators of extensive zoogeographical patterns are recognised as good models for studying biogeography (e.g. Carney and Dick, 2000; Poulin, 2003; Mejía-Madrid et al., 2007; Waltari et al., 2007; Pais et al., 2008), they are remarkably scarce. Exceptions are some studies concerning the parasite fauna of economically important and well-studied fish species (e.g. Rohde and Hayward, 2000), although results have led to different conclusions. Blaylock et al. (1998) investigated the parasite fauna of adult Hippoglossus stenolepis (Schmidt, 1904) from 15 localities along the North American coast and defined three zoogeographic zones consistent with the ones previously established using the distribution of fishes and invertebrates. Furthermore, by examining the ectoparasite fauna of Sebastes capensis (Valenciennes, 1833) along its distribution range (Chilean, Argentinean and South African coasts), González and Moreno (2005) found that parasite communities did not follow the biogeographic pattern known for other marine species in the southeastern Pacific. Similar results were obtained by Byrnes and Rohde (1992) and Hayward (1997) for the ectoparasite fauna of four species of Sparidae of Australia and 26 species of Sillaginidae from the IndoWest Pacific, respectively. However, after examining the endoparasite fauna of $S$. capensis, González et al. (2006) concluded that its biogeographic pattern was concordant with that of free-living organisms.

Pleuronectiformes (flatfish) are a convenient group for studying biogeography and host-parasite interactions since they are monophyletic in origin
(Berendzen and Dimmick, 2002; Pardo et al., 2005; Kartavtsev et al., 2007) but have evolved different ecological strategies and life-history patterns. This diversity and their cosmopolitan occurrence offer an excellent opportunity to investigate whether the biogeography of Pleuronectiformes' parasites follows that of their hosts or is highly dependent on the parasite itself, i.e. whether some kind of predictability of host-parasite associations (at the species or family level) can be depicted by evaluating parasite assemblages in several different areas. Comparisons of the parasite species infecting different flatfish species within the same area and infecting the same host species in different areas can be instruments for this investigation.

In a previous study comprising all flatfish species inhabiting the Atlantic Ocean, Marques et al. (2005) suggested that the parasitological relationships between the widely distributed families Scophthalmidae, Pleuronectidae and Soleidae, were influenced by the overlapping distribution of species of these families along the Portuguese coast. Indeed, given its physical and biological characteristics, a "Lusitanian marine province" has been suggested for the Portuguese coast (e.g. Dana, 1853). However, according to the current classification, it constitutes an important border area between the two major zoogeographic regions defined for the North Atlantic: the cool temperate and warm temperate (Briggs, 1974; Gubbay, 1995).

In the present study, the parasite fauna of Pleuronectiformes inhabiting the Portuguese coast was investigated and compared with that known in four other areas (the North Sea, north Northeast Atlantic, Mediterranean Sea and Northwest African coast) in order to 1) determine the biogeography of parasite taxa and 2) the importance of the Portuguese coast in the establishment of the patterns found.

\section{MATERIALS AND METHODS}

\section{Sampling and data collection}

Twenty species of Pleuronectiformes belonging to five different families (Table 1) were obtained 
TABLE 1. - Macroparasites recorded from Pleuronectiformes on the Portuguese coast, their site of infection (Site), biogeographic distribution (Biog) and total number of host species (TNHsp). Citharidae (C): CL, Citharus linguatula (Linnaeus, 1758). Bothidae (B): AL, Arnoglossus laterna (Walbaum, 1792); AI, Arnoglossus imperialis Rafinesque, 1814. Scophthalmidae (S): LB, Lepidorhombus boscii (Risso, 1810); LW, Lepidorhombus whiffiagonis (Walbaum, 1792); SR, Scophthalmus rhombus (Linnaeus, 1758); SM, Scophthalmus maximus (Linnaeus, 1758); PR, Phrynorhombus regius (Bonnaterre, 1788); ZP, Zeugopterus punctatus (Bloch, 1787). Pleuronectidae (P): PF, Platichthys flesus (Linnaeus, 1758). Soleidae (L): DC, Dicologlossa cuneata (Moreau, 1881); MA, Microchirus azevia (Capello, 1868); MV, Microchirus variegatus Desoutter, 1990; MB, Microchirus boscanion (Chabanaud, 1926); MH, Monochirus hispidus Rafinesque, 1814; SK, Solea kleinii (Bonaparte, 1832); SL, Solea lascaris (Risso, 1810); SN, Solea senegalensis Kaup, 1858; SS, Solea solea (Linnaeus, 1758); SY, Synaptura lusitanica Capello 1868. TNPsp, total number of macroparasite species. Site: S, skin; G, gills; D, digestive tract; V, visceral cavity; B, branchial arches; $\mathrm{M}$, mesenteries. (*) indicates parasites which have only been found infecting flatfishes. Abbreviations for biogeographic distribution are given in the legend to Figure 1. Med, Mediterranean Sea; Indo, Indopacific region.

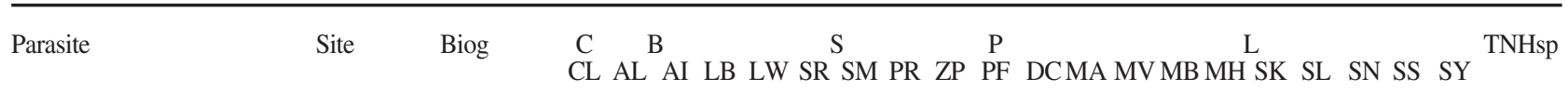

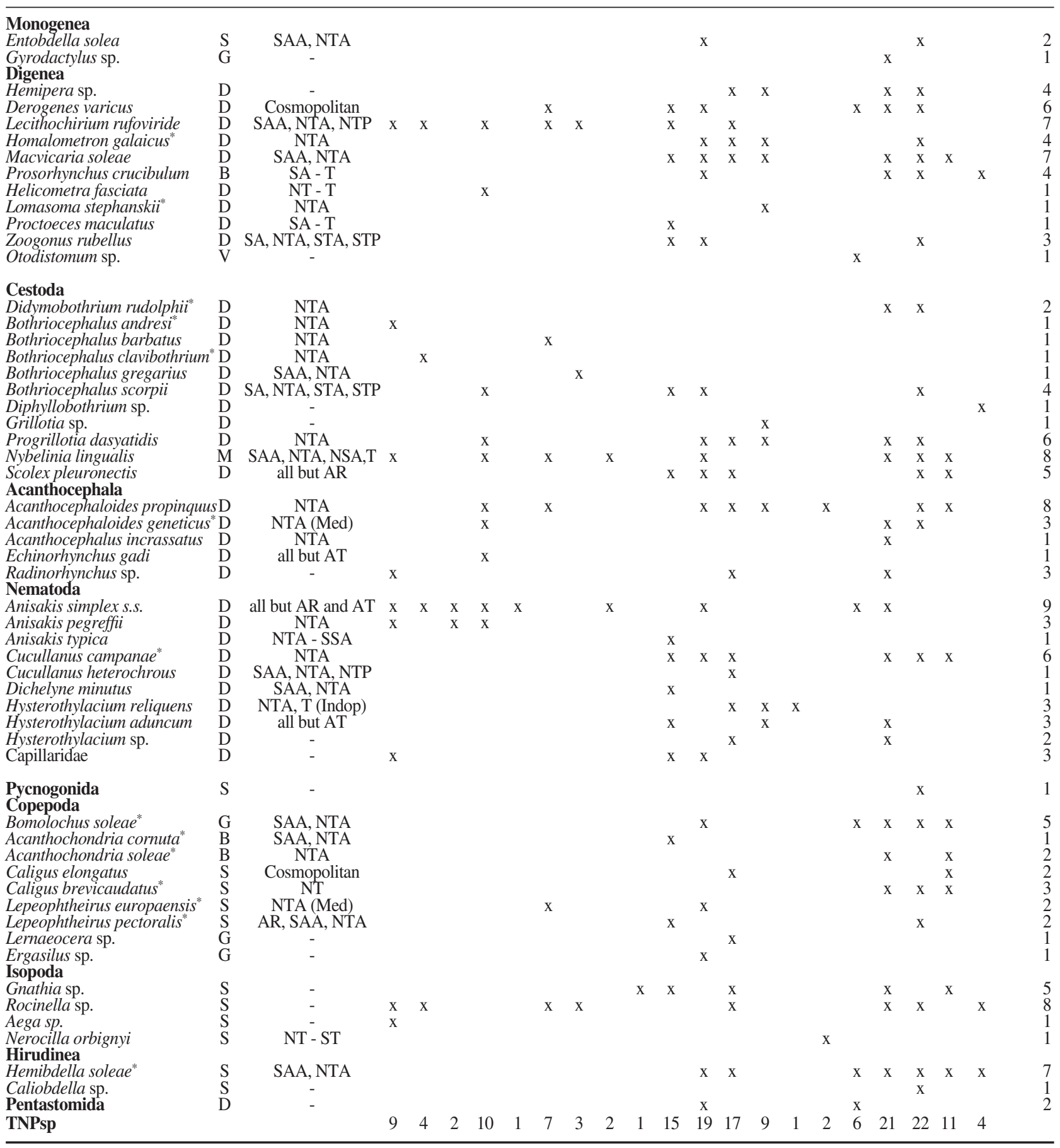




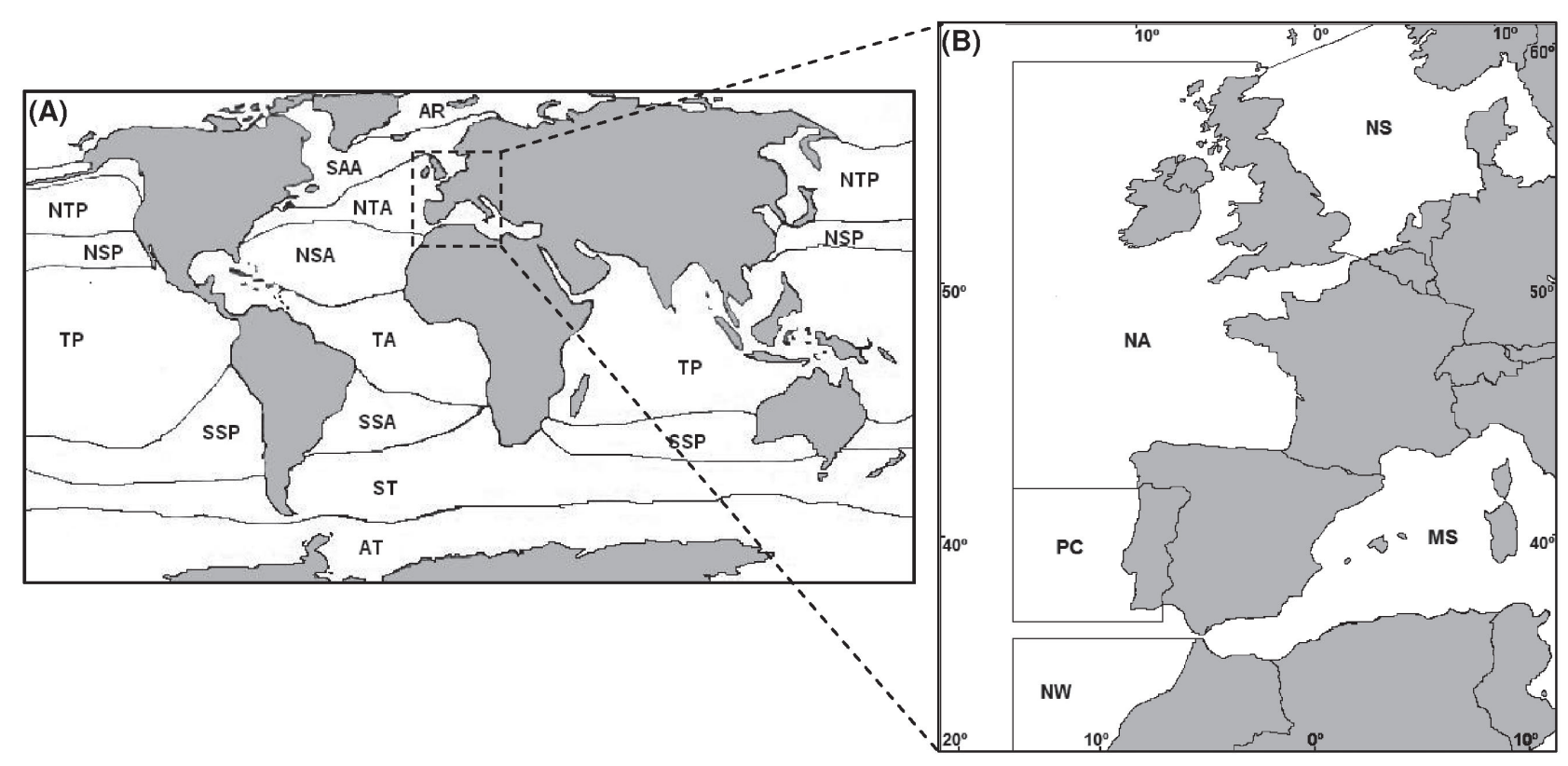

FIG. 1. - Zoogeographic regions used in the classification of macroparasites (A) and the five areas considered in the present study (B). AR, Arctic; SAA, Subarctic Atlantic; NTA, North temperate Atlantic; NTP, North temperate Pacific; NSA, North subtropical Atlantic; NSP, North subtropical Pacific; TA, tropical Atlantic; TP, tropical Pacific; SSA, South subtropical Atlantic; SSP, South subtropical Pacific; ST, South temperate; AT, Antarctic (Modified from Moyle and Cech, 1996). NS, North Sea; NA, north Northeast Atlantic; PC, Portuguese Coast; MS, Mediterranean Sea; NW, Northwest African coast.

from commercial fishing vessels seasonally along the Portuguese coast between January 2003 and July 2005. Because all fish of each species were adults of a similar size range and sampled at an identical depth and habitat, they were pooled into one sample. Samples collected in different areas (north, centre and south) and seasons were also pooled so that parasite assemblages of each host species could be representative of the entire area and comprise all species, including those with marked seasonal patterns. All sampled fish (480 individuals of each species) were then examined for macroparasites and these were collected, counted and identified to the lowest taxonomic level possible.

The current distribution of macroparasites was obtained from the host-parasite database of the Natural History Museum (UK), the European register of marine species (ERMS - MarBef), the ocean biogeographic information system (OBIS) and peer reviewed published papers, and classified according to the biogeographic regions defined by Briggs (1974) (Fig. 1A): Arctic, North temperate, North subtropical, Tropical, South subtropical, South temperate and Antarctic. In order to investigate macroparasite distribution patterns in the distribution range of the flatfish species considered in the present study (obtained from Froese and Pauly, 2006), five areas were considered (Fig. 1B): the North Sea, north Northeast
Atlantic (from northern Scotland - 57 $59^{\prime} \mathrm{N}, 4^{\circ} 57^{\prime} \mathrm{W}$ to the northwest coast of Spain $-41^{\circ} 21^{\prime} \mathrm{N}, 8^{\circ} 53^{\prime} \mathrm{W}$ ), Portuguese coast, Northwest African coast (from Senegal to Morocco) and Mediterranean Sea. Data on flatfish macroparasite infections in these areas were obtained from the literature (Nicoll, 1915; Williams, 1959; MacKenzie and Gibson, 1970; Gibson, 1972; Rodrigues et al., 1975a,b; Papoutsoglou and Papaparaskeva-Papoutsoglou, 1977; van den Broek, 1979a,b; Carvalho-Varela and Cunha-Ferreira, 1987; Petter and Radujkovic, 1989; Renaud and Gabrion, 1988; Zeddam et al., 1988; de Meeus et al., 1992; Belghyti et al., 1993; Cordero del Campillo et al., 1994; Lile et al., 1994; Petter and Cabaret, 1995; Van Damme and Ollevier, 1996; El-Darsh and Whitfield, 1999; Palm et al., 1999; Álvarez et al., 2002; Bartoli et al., 2005) and compiled in a presence/absence matrix together with the data resulting from the parasitological examination of individuals collected along the Portuguese coast.

\section{Data analyses}

As in most biogeography studies (e.g. Carney and Dick, 2000; McDowall, 2000; Rohde, 2002), the present one compiles data from different sources. In order to diminish bias due to methodological differences, only those studies using standard parasi- 
tological methods, similar and large sample sizes and formally described macroparasites identified to the species level were considered. The validity of species' abundance and its evolution over time could not be determined from the consulted studies, so presence/absence data was selected as the best measure of diversity. Although presented in Table 1, infection data from host species presenting sample sizes lower than 30 individuals along the Portuguese coast, such as Lepidorhombus whiffiagonis (Walbaum, 1792), Phrynorhombus regius (Bonnaterre, 1788), Zeugopterus punctatus (Bloch, 1787) and Monochirus hispidus Rafinesque, 1814, were discarded from the comparative analyses, since it has been shown that sample size is a major factor influencing the detection of parasitosis (Poulin, 1998; Marques and Cabral, 2007). Hosts infected by fewer than two macroparasite species were also discarded from the comparative analyses, as they proved to be differentiated from all other samples by not being infected.

Presence/absence data of ectoparasites and endoparasites were analysed separately, as these are influenced by different factors (MacKenzie and Abaunza, 1998) and show considerable differences in their life-cycles - whereas that of ectoparasites is direct, endoparasites require at least one intermediary host. Multivariate analyses were performed at three different scales (host species, host family and area) using the Bray-Curtis dissimilarity since this index accounts for joint presences. A multidimensional scaling (MDS) analysis, using the software PRIMER version 5 (PRIMER-E Ltd., 2001), was applied to host and macroparasite data, in order to reveal the similarity between areas in a two-dimensional space. Similarity between host species and host families was investigated by cluster analysis using the complete linkage agglomeration method, and their significance was tested by bootstrap analysis (1000 re-sampling steps) in Clustering Calculator version 1.0 (University of Alberta, 2002) in order to reveal the association at the area or family level.

\section{RESULTS}

\section{Host-parasite relationships}

Although the 25 species of flatfish inhabiting the Portuguese coast were examined, only 20 of them were infected, harbouring 23652 macroparasite individuals belonging to 56 species (Table 1): 2 Monogenea, 11 Digenea, 11 Cestoda, 5 Acanthocephala, 10 Nematoda, 1 Pycnogonida, 9 Copepoda, 4 Isopoda, 2 Hirudinea and 1 Pentastomida. Most species were endoparasites in the digestive tract and a total of 34 species infected more than one host, generally two or three closely related species, i.e. within the same family. The highest number of macroparasite species was collected from Soleidae: Solea senegalensis Kaup, 1858, Solea lascaris (Risso, 1810), Dicologlossa cuneata (Moreau, 1881) and Microchirus azevia (Capello, 1868) harboured 22, 21, 19 and 17 species, respectively. However, most of the hosts were infected by fewer than 10 macroparasite species, with three of them (L. whiffiagonis, Z. punctatus and Microchirus boscanion (Chabanaud, 1926)) harbouring only one species (Table 1).

According to the currently known distribution of the 40 macroparasites identified to the species level, only the digenean Derogenes varicus (Müller, 1784) and the copepod Caligus elongatus von Nordmann, 1832 were truly cosmopolitan. On the other hand, the acanthocephalan Acanthocephaloides geneticus (Buron, Renaud and Euzet, 1985) and the copepod Lepeophtheirus europaensis Zeddam, Berrebi, Renaud, Raibaut and Gabrion, 1988 had only been reported from flatfishes inhabiting the Mediterranean Sea. The majority of macroparasite species had, nevertheless, a broad distribution in the North temperate Atlantic region or in the Subarctic and North temperate regions of the Atlantic and Pacific (Table 1).

The information collected for the macroparasite species infecting flatfish in the five areas considered in this study showed that most species were reported in more than one area and infecting more than one host. With a few exceptions, macroparasite species found in Pleuronectiformes were also found in other diverse and unrelated marine fish families (Appendix 1, Electronic Supplementary Material). However, within each host, most macroparasite species were found in only one area and, for the more widespread species, one of the areas of distribution was usually the Portuguese coast (Appendix 1, Electronic Supplementary Material).

\section{Zoogeographic patterns}

The multidimensional scaling (MDS) analysis carried out using the presence/absence data of hosts within each area revealed the North Sea (NS) 

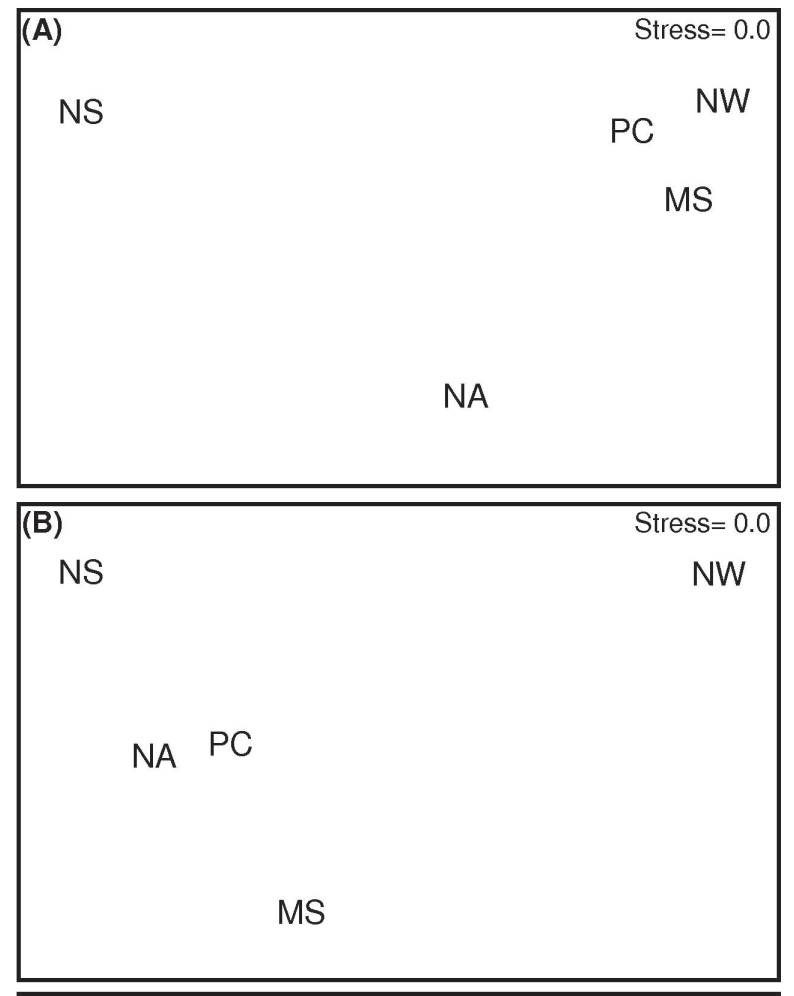

\begin{tabular}{|lll|}
\hline (C) & NA & Stress $=0.0$ \\
& & \\
& & \\
& & \\
& & \\
PC & & \\
\hline
\end{tabular}

FIG. 2. - Multidimensional scaling analysis of the five areas, based on the presence/absence data of (A) Pleuronectiformes species, (B) endoparasites and (C) ectoparasites. Abbreviations for areas are given in the legend of Figure 1. to be the most differentiated area and the Portuguese coast (PC) and the Mediterranean Sea (MS) to be the most similar ones (Fig. 2A). However, the MDS analysis performed on macroparasite data revealed a different pattern: the PC was very similar to the north Northeast Atlantic (NA) with regard to endoparasite data (Fig. 2B), and differentiated from all other areas (widely separated from all other areas in the two-dimensional plot) with regard to ectoparasite data (Fig. 2C). The cluster analysis performed on the presence/absence data of endoparasites within each flatfish family (Fig. 3) showed an overall dissimilarity between families, although phylogenetically closer families (Soleidae and Pleuronectidae; Bothidae and Citharidae) had more similar assemblages, with all clusters being supported by high bootstrap values. The removal of hosts with only one ectoparasite species led to the exclusion of three of the families and the cluster analysis using ectoparasite data was therefore not performed.

When host species were clustered based on their endoparasite fauna (Fig. 4A), most samples were highly differentiated (76.2 bootstrap value associated with the dissimilarity of the seven major clusters), although some species of the same family inhabiting the same area showed small dissimilarities supported by high bootstrap values. The cluster of host species based on their ectoparasite fauna (Fig. 4B) revealed a significantly high similarity between all samples of Platichthys flesus (Linnaeus 1758), regardless of the area where the host was collected, and between species of Solea from the Portuguese coast, the clustering of S. lascaris and $S$. solea being supported by a moderately high bootstrap value (66.7).

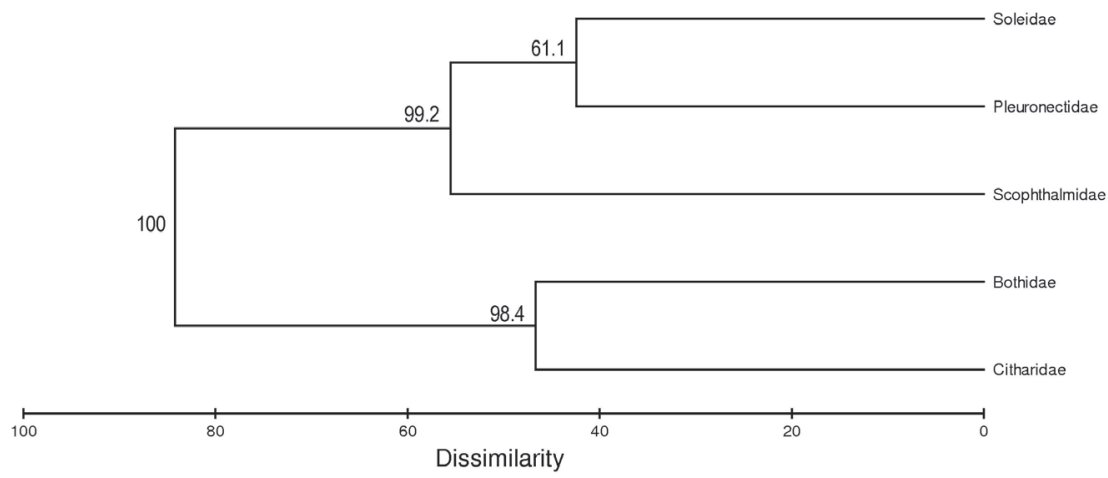

FIG. 3. - Cluster analysis of the Pleuronectiformes families based on the presence/absence data of endoparasite species using the Bray-Curtis similarity index and the complete linkage algorithm. Numbers in cluster nodes indicate bootstrap values (1000 re-sampling steps). 

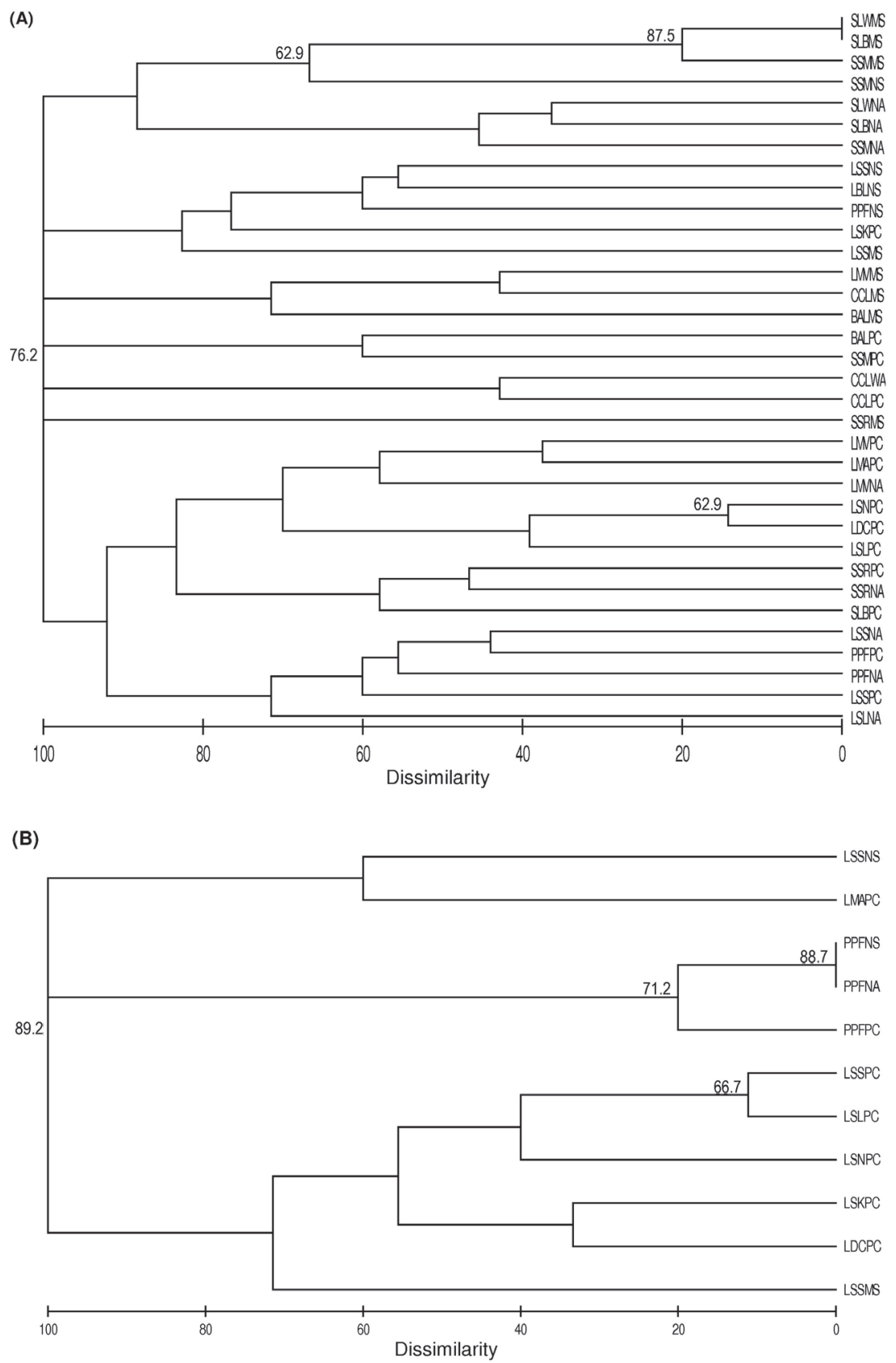

FIG. 4. - Cluster analyses of the Pleuronectiformes species within each area based on the presence/absence data of macroparasite species using the Bray-Curtis dissimilarity index and the complete linkage algorithm: (A), Endoparasites; (B), Ectoparasites. Acronyms are defined by five characters, with the first corresponding to the family, the following two to the species and the last two to the area. Family: C, Citharidae; B, Bothidae; S, Scophthalmidae; P, Pleuronectidae; L, Soleidae. Abbreviations for species are given in Table 1 and for areas in the legend of Figure 1. Numbers in cluster nodes indicate bootstrap values (1000 re-sampling steps).

\section{DISCUSSION}

\section{Host-parasite relationships}

Parasite assemblages have successfully been used in the study of their hosts distribution and relationships, but few studies have used parasites as indicators of larger-scale zoogeographical patterns (e.g. Oliva and González, 2005; Mejía-Madrid et al., 2007; Vinarski et al., 2007; Waltari et al., 2007; Pais et al., 2008). Focusing on widely distributed flatfishes, and covering most of their range, the present study identified some patterns in the host-parasite associations for this group of marine fishes.

According to the 'first law of geography', similarity between two observations decays as their 
geographic distance increases due to a decrease in similarity of their environmental conditions, the existence of geographical barriers between them, or both (Nekola and White, 1999). Since most endoparasite species infecting flatfish are acquired by ingesting invertebrate intermediate hosts whose dispersal is ultimately influenced by oceanic current patterns, the results obtained for the endoparasite fauna might be the reflection of similar environmental conditions between the Portuguese coast and the north Northeast Atlantic, which are the most geographically closest areas and have no geographical barriers between them. A decay of similarity in parasite communities over distance has been reported for other hostparasite assemblages (Poulin, 2003; Krasnov et al., 2005; Oliva and González, 2005). However, because parasites are influenced by the physical environment and the 'host environment', factors such as the host ecology and host species community composition must also play a role in the associations found. In the present study, most endoparasite species were recovered from the generalist Soleidae (Link et al., 2005), which feed on the most abundant Crustacea and Mollusca. Similar environmental characteristics between the north Northeast Atlantic and Portuguese coast might therefore lead to similar feeding ecology of Soleidae in both areas, also contributing to the similarity found.

On the other hand, the distribution of marine ectoparasites, which have direct life-cycles, is mainly determined by the characteristics of the water mass during their brief free-living stage, and by the host's dispersal ability when they are adults (Mackenzie and Abaunza, 1998; Bush et al., 2001). This gives ectoparasites an advantage in biogeographic studies as their distribution is not confounded by factors related to intermediate host abundance (González and Moreno, 2005), and it was expected that areas with similar host assemblages would also have similar ectoparasite assemblages. However, similarly to reports from other studies using marine fish ectoparasites (e.g. Byrnes and Rohde, 1992; Hayward, 1997; González and Moreno, 2005), no congruence was found between the distribution of flatfish and that of their ectoparasites, with the Portuguese coast being highly differentiated from all other areas. Host distribution, abundance and behaviour, alone or in conjunction, might have contributed to this differentiation.

Host-parasite evolutionary relationships have been the subject of several studies (e.g. Mas-Coma,
1992; Sasal et al., 1998; Rohde, 2002; Stireman, 2005) and a positive relationship has been found between the diversity of hosts and the diversity of parasites within one area and between parasite and host phylogenies. The present study is in agreement with these findings, since the most diverse family within the Portuguese coast, the Soleidae, showed a higher number of parasite species than the least represented families, such as the Citharidae or the Bothidae. Results also indicate that more closely related families, such as the Soleidae and the Pleuronectidae, have more similar macroparasite faunas, as evidenced by the cluster analysis performed on families of hosts. However, the high variability of the macroparasite faunas among hosts inhabiting different areas, evidenced by the low similarities obtained in the cluster analyses of both endoparasites and ectoparasites, suggests that host-parasite associations result mostly from environmental-driven evolution. Under this scenario, no predictability of host-parasite associations can be made, except for specific parasites, such as Acanthochondria cornuta (Müller, 1776) and Lepeophtheirus pectoralis (Müller, 1776), whose distribution actually mirrors that of their host, Platichthys flesus (Linnaeus, 1758), as revealed by the significant similarity between $P$. flesus ectoparasite assemblages regardless of the area where the fish were sampled.

\section{Zoogeographic patterns}

The endoparasite fauna of flatfishes inhabiting the Portuguese coast appears to be dominated by Subarctic and North temperate Atlantic species that also occur in other marine fish, their zoogeographical pattern being generally consistent with that of marine free-living species. The wide distribution of Monogenea and Digenea from marine fish and their considerable host specificity (Manter, 1966) led Lebedev (1969) to distinguish 10 zoogeographical regions differing in the composition of their Monogenea and Digenea faunas. In this zoogeographic model, the Portuguese coast was included in the Atlanto-Mediterranean region, which also comprised the Mediterranean and Black Seas and the Atlantic coast of Spain and Morocco. The results obtained in this study are therefore consistent with this model since most Digenea are common between the north Northeast Atlantic and the Portuguese coast or between these areas and the Mediterranean Sea, resulting in a similar endoparasite assemblage between 
these areas, as revealed by the MDS analysis and, to some extent, by the cluster analysis performed on flatfish species.

Although flatfish assemblages from the more southern areas were quite similar (Fig. 2A), some of the species that have their northern distribution limit along the Portuguese coast (Arnoglossus thori Kyle, 1913, Bothus podas (Delaroche, 1809), Dicologlossa hexophthalma (Bennett, 1831), Microchirus ocellatus (Linnaeus, 1758)) are not abundant in this area, resulting in low sampling sizes and their exclusion from the comparative analyses of macroparasite assemblages, and increasing the discrepancy between host and macroparasite infections results. Ecological host-switching (Poulin, 1998; Page, 2003), through the contagious transmission of generalist ectoparasites between similar host species, or between widespread host species and those living near the limit of their distribution range, might be promoted by the high overlap of host species along the Portuguese coast. However, the relatively sedentary behaviour of adult flatfishes might contribute to a minimal dispersion of these ectoparasite species, resulting in a higher richness in this area and its differentiation from the other four considered.

Despite all the ecological factors pointed out so far, historical reasons cannot be ruled out to explain the results found in the present study. The origin and distribution of the great majority of our present species probably took place in tropical centres during the Pliocene and Pleistocene (Briggs, 2006), and Atlantic and Mediterranean marine faunas are no exception. Results from a palaeontologic study conducted in the central region of the Portuguese coast $\left(40^{\circ} \mathrm{N}\right)$, indicates that the Pliocenic faunal association in this area had a typical Atlantic affinity, with no fossil species from the Mediterranean being found and two exclusively Atlantic fossil species being present (Nolf and Marques da Silva, 1997). After the mass extinction of Mediterranean fauna due to the Messinian salinity crisis, in the early Pliocene, this area was colonised by warm temperate Atlantic species that are found here, and on the western coast of Africa, their refuges during the Pleistocene glaciations, before they recolonised temperate eastern Atlantic waters when conditions were favourable (Almada et al., 2001; Domingues et al., 2008). These events offer a possible explanation for the similarity found between flatfish communities along the Portuguese coast, Mediterranean Sea and Northwest African coast, and also for the differences found between macroparasite assemblages: some parasite lineages established in flatfishes might have been lost when hosts migrated southwards (warm-temperate species) during glaciation peaks, due to extreme differences in environmental conditions or the absence of the required intermediate hosts to complete their life-cycles; glacial advances and retreats during the Pleistocene and the recent (less than 10000 years, after the last ice-age) colonisation of the Portuguese coast by some subtropical species (e.g. D. hexophthalma, M. ocellatus, also found in the warmer waters of the Mediterranean and Northwest African coast) have not yet allowed the development of stable hostparasite relationships. This is supported by the fact that most macroparasite species found in the present study had Subartic and North temperate distributions and infected hosts with temperate affinities, suggesting that similarities found between parasite faunas from Pleuronectiformes inhabiting the north Northeast Atlantic and the Portuguese coast are the result of long-lasting interactions between parasites and their hosts.

Results of the present study point out the high importance of the Portuguese coast as a transition area in shaping macroparasite assemblages of Pleuronectiformes species occurring in the Northeast Atlantic and Mediterranean Sea and in the establishment of host-parasite relationships, as suggested by Marques et al. (2005). The sympatric occurrence of closely related host species along this area, allows the colonisation of new, but similar, hosts by macroparasites specific at the genus or family level through evolutionary events, but also the continuum of host-parasite relationships involving specific parasite lineages. However, phylogenies of both parasites and hosts are essential in the study of the biogeography of the extant biodiversity (Cowie and Holland, 2006), and knowledge of the macroparasite faunas infecting Pleuronectiformes in more remote regions and of the rare Pleuronectiformes species occurring along the Portuguese coast are needed in order to clarify the relationships found in the present study.

\section{ACKNOWLEDGMENTS}

This study was partially financed by the Fundação para a Ciência e a Tecnologia (FCT), Portugal, through the grant attributed to J.F. Marques (Grants SFRH/BD/8983/2002 and SFRH/BPD/26999/2006). This study was co-funded by the European Union 
through the FEDER - Fisheries Programme (MARE). The authors would like to thank Dr. R. Poulin and Dr. A. Patterson for their comments on previous versions of this manuscript. The authors would also like to express their gratitude to Dr. Enric Massutí, Scientific Editor of Scientia Marina, and two anonymous referees for their comments and suggestions. All the experiments comply with the current laws of the country in which they were performed.

\section{REFERENCES}

Almada, V.C., R.F. Oliveira, E.J. Gonçalves, A.J. Almeida, R.S. Santos and P. Wirtz. - 2001. Patterns of diversity of the northeastern Atlantic blennid fish fauna (Pisces: Blenniidae). Global Ecol. Biogeogr., 10: 411-422.

Álvarez, F., R. Iglesias, A.I. Paramá, J. Leiro and M. Sanmartín. - 2002. Abdominal macroparasites of commercially important flatfishes (Teleostei: Scophtalmidae, Pleuronectidae, Soleidae) in the northwest Spain (ICES IXa). Aquaculture, 213: 31-53.

Bartoli, P., D.I. Gibson and R.A. Bray. - 2005. Digenean species diversity in teleost fish from a nature reserve off Corsica, France (Western Mediterranean), and a comparison with other Mediterranean regions. J. Nat. Hist., 39: 47-70.

Belghyti, D., P. Aguesse and C. Gabrion. - 1993. Éthologie Alimentaire de Citharus linguatula et Dicologoglossa cuneata sur les côtes atlantiques du Maroc. Vie Milieu, 43: 95-108.

Berendzen, P.B. and W.W. Dimmick. - 2002. Phylogenetic relationships of Pleuronectiformes based on molecular evidence. Copeia, 3: 642-652.

Blaylock, R.B., L. Margolis, J.C. Holmes. - 1998. Zoogeography of the parasites of Pacific halibut (Hippoglossus stenolepis) in the northeast Pacific. Can. J. Zool., 76: 2262-2273.

Briggs, J.C. - 1974. Marine Zoogeography. McGraw-Hill, New York.

Briggs, J.C. - 2006. Proximate sources of marine biodiversity. $J$. Biogeogr., 33: 1-10

Bush, A.O., J.C. Fernadez, G.W. Esch and J.R. Seed. - 2001. Parasitism: the diversity and ecology of animal parasites. Cambridge University Press, Cambridge.

Byrnes, T. and K. Rohde. - 1992. Geographical distribution and host specificity of ectoparasites of Australian bream, Acanthopagrus spp. (Sparidae). Folia Parasitol., 39: 249-264.

Carney, J.P. and T.A. Dick. - 2000. Parasite biogeography: a review of the origins and ideas with specific examples from holarctic fishes. Vie Milieu, 50: 221-243.

Carvalho-Varela, M. and V. Cunha-Ferreira. - 1987. Helminth parasites of the common sole, Solea solea, and the senegalese sole, Solea senegalensis, on the Portuguese continental coast. Aquaculture, 67: 135-138.

Cordero del Campillo, M., L.C. Ordóñez and A.R. Feo. - 1994. Indice-Catálogo de Zooparásitos Ibéricos. Universidad de Léon, Léon.

Cowie, R.H. and B. S. Holland. - 2006. Dispersal is fundamental to biogeography and the evolution of biodiversity on oceanic islands. J. Biogeogr., 33: 193-198.

Dana, J.D. - 1853. On an isothermal oceanic chart illustrating the geographical distribution of marine animals. Am. J. Sci., 66: 153-157.

de Meeus, T., R. Marin and F. Renaud. - 1992. Genetic heterogeneity within populations of Lepeophtheirus europaensis (Copepoda: Caligidae) parasitic on two host species. Int. J. Parasitol., 22: 1179-1181.

Domingues, V.S., M. Alexandrou, V.C. Almada, D.R. Robertson, A. Brito, R.S. Santos and G. Bernardi. - 2008. Tropical fishes in a temperate sea: evolution of the wrasse Thalassoma pavo and the parrotfish Sparisoma cretense in the Mediterranean and the adjacent Macaronesian and Cape Verde Archipelagos. Mar. Biol., 154: 465-474.

El-Darsh, H.E.M. and P.J. Whitfield. - 1999. The parasite commu- nity infecting flounders, Platichthys flesus, in the tidal Thames. J. Helminthol., 73: 203-214.

Froese, R. and D. Pauly. - 2006. FishBase. World Wide Web electronic publication. www.fishbase.org, version (02/2006).

Gibson, D.I. - 1972. Flounder parasites as biological tags. J. Fish Biol., 4: 1-9.

González, M.T. and C.A. Moreno. - 2005. The distribution of the ectoparasite fauna of Sebastes capensis from the southern hemisphere does not correspond with zoogeographical provinces of free-living marine animals. J. Biogeogr., 32: 1539-1547.

González, M.T., C. Barrientos and C.A. Moreno. - 2006. Biogeographical patterns in endoparasite communities of a marine fish (Sebastes capensis Gmelin) with extended range in the Southern Hemisphere. J. Biogeogr., 33: 1086-1095.

Gubbay, S. - 1995. Marine region 5: Northeast Atlantic. In: The World Bank, The World Conservation Union (IUCN), Great Barrier Reef Marine Park Authority (eds.), A Global Representative System of Marine Protected Areas, Volume 1. Australian Government, Australia.

Hayward, C.J. - 1997. Distribution of external parasites indicates boundaries to dispersal of sillaginid fishes in the Indo-West Pacific. Mar. Freshw. Res., 48: 391-400.

Kartavtsev, Y.P., T.-J. Park, K.A. Vinnikov, V.N. Ivankov, S.N. Sharina and J.-S. Lee. - 2007. Cytochrome b (Cyt-b) gene sequence analysis in six flatfish species (Teleostei, Pleuronectidae), with phylogenetic and taxonomic insights. Mar. Biol., 152: 757-773.

Krasnov, B.R., G.I. Shenbrot, D. Mouillot, I.S. Khokhlova and R. Poulin. - 2005. Spatial variation in species diversity and composition of flea assemblages in small mammalian hosts: geographic distance or faunal similarity? J. Biogeogr., 32: 633-644.

Lebedev, B.I. - 1969. Basic regularities in the distribution of monogeneans and trematodes of marine fishes in the world ocean. Zool. Zh., 48: 41-50.

Lile, N.K., O. Halvorsen and W. Hemmingsen. - 1994. Zoogeographical classification of the macroparasite faunas of four flatfish species from the northeastern Atlantic. Polar Biol., 14: 137-141.

Link, J.S., M.J. Fogarty and R. Langton. - 2005. The trophic ecology of flatfishes. In: R.N. Gibson (ed.), Flatfishes Biology and Exploitation, pp. 185-212. Blackwell Publishing, Oxford.

MacKenzie, K. and P. Abaunza. - 1998. Parasites as biological tags for stock discrimination of marine fish: a guide to procedures and methods. Fish. Res., 38: 45-56.

MacKenzie, K. and D.I. Gibson. - 1970. Ecological studies of some parasites plaice and flounder. In: A. Taylor and R. Muller R (eds.), Aspects of fish parasitology. Symp. Br. Soc. Parasitol., 8: $1-42$.

Manter, H.W. - 1966. The zoogeography of trematodes of marine fishes. Exp. Parasitol., 4: 62-86.

Marques, J.F. and H.N. Cabral. - 2007. Effects of sample size on fish parasites prevalence, mean abundance and mean intensity estimates. J. Appl. Ichthyol., 23: 158-162.

Marques, J.F., M.J. Santos and H.N. Cabral. - 2005. Biogeography of parasites of Pleuronectiformes (Pisces) in the North Atlantic. Proc. IX Eur. Multicolloq. Parasitol., 2: 493-498.

Mas-Coma, S. - 1992. Parasitologia ecologica y evolutiva: aspectos aplicados. Avances en Parasitología, Protozoologia, pp: 43-65. Universidade de Santiago de Compostela, Santiago de Compostela.

McDowall, R.M. - 2000. Biogeography of the southern cool-temperate galaxioid fishes: evidence from metazoan macroparasite faunas. J. Biogeogr., 27: 1221-1229.

Mejía-Madrid, H.H., E. Vázquez-Domínguez and G. Pérez-Ponce de León. - 2007. Phylogeography and freshwater basins in central Mexico: recent history as revealed by the fish parasite Rhabdochona lichtenfelsi (Nematoda). J. Biogeogr., 34: 787-801.

Mosquera, J., M. Gómez-Gesteira and V. Pérez-Villar. - 2000. Using parasites as biological tags of fish populations: a dynamical model. Bull. Math. Biol., 62: 87-99.

Moyle, P.B. and J.J. Cech. - 1996. Fishes: An introduction to ichthyology. Prentice Hall, New Jersey.

Nekola, J.C. and P.S. White. - 1999. The distance decay of similarity in biogeography and ecology. J. Biogeogr., 26: 867-878.

Nicoll, W. - 1915. A list of trematode parasites of British marine fishes. Parasitology, 7: 339-378.

Nolf, D. and C. Marques da Silva. - 1997. Otolithes de poissons 
pliocènes (Plaisancien) de Vale de Freixo, Portugal. Rev. Micropaléonthol., 40: 273-282.

Oliva, M.E. and M.T. González. - 2005. The decay of similarity over geographical distance in parasite communities of marine fishes. J. Biogeogr., 32: 1327-1332.

Page, R.D.M. - 2003. Tangled trees: phylogeny, cospeciation, and coevolution. University of Chicago Press, Chicago.

Pais, A., P. Merella, M.C. Follesa, G. Garippa and D. Golani. - 2008 New data on Gaidropsarus granti (Regan, 1903) (Gadiformes: Lotidae) from the Mediterranean Sea, with emphasis on its parasites. Sci. Mar., 72: 461-468.

Palm, H.W., S. Klimpel and C. Bucher. - 1999. Checklist of metazoan fish parasites of German coastal waters. Institut für Meereskunde an der Christian-Albrechts-Universität Kiel, Kiel.

Papoutsoglou, S.E. and E.G. Papaparaskeva-Papoutsoglou. - 1977. Metazoan parasites of Solea solea (L.) from Porto-Largo, north Aegean Sea, Greece. Mem. Biol. Mar. Oceanogr., 7: 21-33.

Pardo, B.G., A. Machordom, F. Foresti, M.F.C. Azevedo, R. Bañón, L. Sánchez and P. Martínez. - 2005. Phylogenetic analysis of flatfish (Order Pleuronectiformes) based on mitochondrial 16S rDNA sequences. Sci. Mar., 69: 531-543.

Petter, A.J. and J. Cabaret. - 1995. Ascaridoid nematodes of teleostean fishes from the eastern North Atlantic and Seas of the north of Europe. Parasite, 2: 217-223.

Petter, A.J. and B.M. Radujkovic. - 1989. Parasites des poissons marins du Montenegro: Nematodes. Acta Adriat., 30: 195-236.

Poulin, R. and S. Morand. - 2000. The diversity of parasites. Q. Rev. Biol., 75: 277-293.

Poulin, R. - 1998. Evolutionary ecology of parasites: from individuals to communities. Chapman and Hall, London.

Poulin, R. - 2003. The decay of similarity with geographical distance in parasite communities of vertebrate hosts. J. Biogeogr., 30: $1609-1615$

Renaud, F. and C. Gabrion. - 1988. Speciation of cestoda: Evidence of two sibling species in the complex Bothrimonus nylandicus (Schneider 1902) (Cestoda: Cyathocephalidea). J. Parasitol., 97: 139-147.

Rodrigues, H.O., M. Carvalho-Varela, S.S. Rodrigues and R. Cristofaro. - 1975a. Nova contribuição para o estudo dos nematódeos de peixes do oceano Atlântico - costa continental Portuguesa e costa do Norte da África. Mem. Inst. Oswaldo Cruz, 73: 127-134.

Rodrigues, H.O., D. Noronha and M. Carvalho-Varela. - 1975b. Alguns acantocéfalos de peixes do oceano Atlântico, costa continental Portuguesa e costa do Norte da África. Mem. Inst. Oswaldo Cruz, 73: 209-214.

Rohde, K. - 2002. Ecology and biogeography of marine parasites. Adv. Mar. Biol., 43: 1-86.
Rohde, K. and C.J. Hayward. - 2000. Oceanic barriers as indicated by scombrid fishes and their parasites. Int. J. Parasitol., 30: 579-583.

Sasal, P., Desdevises, Y. and S. Morand. - 1998. Host-specialization and species diversity in fish parasites: phylogenetic conservatism? Ecography, 21: 639-643.

Stireman, J.O. - 2005. The evolution of generalization? Parasitoid flies and the perils of inferring host range evolution from phylogenies. J. Evol. Biol., 18: 325-336.

Van Damme, P.A. and F. Ollevier. - 1996. The population dynamics of Lernaeocera lusci and L. branchialis on intermediate hosts. Helgol. Meeresunters., 50: 177-190.

van den Broek, W.L.F. - 1979a. Copepod ectoparasites of Merlangius merlangus and Platichthys flesus. J. Fish Biol., 14: 371-380.

van den Broek, W.L.F. - 1979b. Infection of estuarine populations of Cryptocotyle lingua (Creplin). J. Fish Biol., 14: 395-402.

Vinarski, M.V., N.P. Korallo, B.R. Krasnov, G.I. Shenbrot and R. Poulin. - 2007. Decay of similarity of gamasid mite assemblages parasitic on Palaearctic small mammals: geographic distance, host-species composition or environment. J. Biogeogr., 34: 1691-1700

Waltari, E., E.P. Hoberg, E.P. Lessa and J.A. Cook. - 2007. Eastward Ho: phylogeographical perspectives on colonization of hosts and parasites across the Beringian nexus. J. Biogeogr., 34: $561-574$.

Williams, H.H. - 1959. A list of parasitic worms, including 22 new records, from marine fishes caught off the British Isles. Ann. Mag. Nat. Hist., ser. 13: 705-715.

Zeddam, J.L., P. Berrebi, F. Renaud, A. Raibaut and C. Gabrion. - 1998. Characterization of two species of Lepeophtheirus (Copepoda, Caligidae) from flatfishes. Description of Lepeophtheirus europaensis sp. nov.. Parasitology, 96: 129-144.

Scient. ed.: E. Massutí.

Received June 17, 2008. Accepted November 21, 2008.

Published online April 6, 2009.

\section{SUPPLEMENTARY MATERIAL}

The following appendix is available through the web page http://www.icm.csic.es/scimar/supplm/sm73n3461sm.pdf

APPENDIX 1. - Macroparasites recorded from the Pleuronectiformes species considered in the present study in the North Sea (NS), Northeast Atlantic (NA), Portuguese coast (PC), Mediterranean Sea (MS) and Northwest coast of Africa (NW). 